\title{
$\mathbf{R}$ (on the application of Rudewicz and others) $\mathbf{v}$ Ministry of Justice \\ Divisional Court: Hallett LJ, McCombe J, October 2011 \\ Exhumation - Secretary of State's licence
}

The applicants sought a judicial review of the Home Secretary's decision permitting the exhumation and re-interment of the remains of Father Jarzebowski, a Polish priest from the Marian Fathers' foundation at Fawley Court. The priest had been instrumental in founding a school there for Polish students displaced by the Second World War. The applicants relied upon the presumption against exhumation without a proper reason and argued that the exhumation constituted disrespect for the priest's wishes and for Polish heritage, and would cause stress to the Polish community. In addition, the fourth claimant argued that, as the priest's nearest relative, the exhumation was an interference with her Article 8 right to family life and Article 9 right to manifest her religion. The Marian Fathers, supported by the local bishop, wanted the priest's body reinterred at Fairmile Cemetry, along with fellow priests of his Order, allowing the many visitors to the priest's grave to visit without obstacle. By contrast, at Fawley Court access would be restricted to annual visits on All Saints Day and exceptional visits at the discretion of the owners. The court upheld the decision to allow the exhumation. There was nothing in the decision incompatible with Article 9 of the ECHR, as permanence of burial is not a basic tenet of Roman Catholic faith and the hierarchy of the Catholic Church supported the exhumation. Further, the fourth claimant's Article 8 rights were not engaged; she had never met the deceased priest so no family life was established nor can family life subsist after death. It was with the Marian Fathers that the priest lived the majority of his life and their constitution, at least when he entered religious life, treated the Head of the Order as next of kin with right to determine the site of burial. [Catherine Shelley]

doi:10.1017/So956618X1200018X

\section{Re St Peter and St Paul, Over Stowey}

Bath and Wells Consistory Court: Briden Ch, November 2011 Pipe organ - electronic replacement

A faculty was granted for the removal of a mid-nineteenth century pipe organ situated in the north chapel of the church and its replacement with an electronic instrument. Letters of objection had been received from the Victorian Society, the British Institute of Organ Studies and four individuals. The chancellor held that there was a strong presumption in favour of pipe organs, as opposed to electronic replacements, for use in parish churches. While not accepting certain claims by the Victorian Society as to the historic interest of 